\title{
"And the Word Dwelt amongst Us": Experiencing the Nativity in the Italian Renaissance Home
}

\author{
Zuzanna Sarnecka
}

Volo enim illius pueri memoriam agere, qui in Bethlehem natus est, et infantilium necessitatum eius incommoda, quomodo in praesaepio reclinatus et quomodo, adstante bove atque asino, supra foenum positus exstitit, utcumque corporeis oculis pervidere. ${ }^{1}$

ST FRANCIS TO A NOBLEMAN GIOVANNI FROM GRECCIO

This fragment from the biography of St Francis shows the origins of the practice of re-enactments of the Nativity. ${ }^{2}$ The poverello from Assisi visited Bethlehem, the historical birthplace of Christ, and asked Pope Honorius II I for approval for his pious project of recreating the Incarnation. St Francis wished to see with his 'corporeal eyes' the Christ Child lying in the manger guarded by ox and ass, deprived of any luxuries. In 1223 he shared his ambition to celebrate the birth of Christ with a certain Giovanni from Greccio, who assisted him in fulfilling that spiritual desire. People from the small, Umbrian village spared no efforts in order to make manifest the saint's vision, in such a way that 'Greccio was transformed into a seemingly new Bethlehem', 'et quasi nova Bethlehem de Graecio facta est'. 3 The miracle that took place during the mass at Greccio,

1 Celano Thomas de, Vita prima S. Francisci Assisiensis et eiusdem legenda ad usum chori (Rome: 1926) 90. 'For I wish to enact the memory of the Babe who was born in Bethlehem: to see as much as possible with my own bodily eyes the discomfort of his infant needs, how he lay in a manger, and how, with an ox and an ass standing by, he rested on hay'. Translation from Celano Thomas de, The Francis Trilogy of Thomas of Celano (Hyde Park, New York: 2004) 94-95.

2 Frugoni C., "Sul Natale di Greccio e le sue rappresentazioni", in Frugoni C. - Siddi F. (eds.), Il mistero gioioso. Il presepe di Greccio e le sculture del Gesù Bambino benedicente (Siena: 2012) 11-31.

3 Celano, Vita prima S. Francisci Assisiensis 90.

(C) ZUZANNA SARNECKA, 2019 | DOI:10.1163/9789004375871_009

This is an open access chapter distributed under the terms of the prevailing CC-BY-NC-ND License at the time of publication. 
when during St Francis's re-enactment the newly-born Christ apparently became physically present, nourished the demand for sculptural recreations of presepi. From the communal desire to act out the sacred mystery of God made man, arose the tradition of placing inside churches figures of the Christ Child with his Virgin mother, and other attendant figures such as St Joseph, the adoring Magi, the shepherds, and the asses and oxen.

The first three-dimensional presepe known to us was commissioned by Pope Nicholas IV (1288-1292) for Santa Maria Maggiore in Rome. Its purpose was to recreate for all to see with their bodily eyes the events that took place in Bethlehem. ${ }^{4}$ As the first Franciscan pope, Nicholas continued the mission of St Francis of bringing the Nativity closer to the faithful. Undoubtedly, the sculptural recreation by Arnolfo di Cambio was both visually and spiritually powerful, in particular since in the crypt in the main nave of the basilica, underneath the high altar, there were relics of the holy crib that had been brought to Rome from the Holy Land in the seventh century. In the late fifteenth century the popularisation of domestic presepi can be linked to the growing popularity of terracotta as a sculptural medium. Through the use of small-scale moulds, of which a few examples still survive, the mass-production of domestic presepi was relatively inexpensive. In particular in the Marche region and in Faenza in Emilia-Romagna potters created diverse representations through the use of different, vivid colours or memorable poses of modelled figurines. This article considers various sculptural forms developed for domestic devotions of the mystery of the Nativity. Objects described in inventories and surviving visual examples suggest that although it began as an ecclesiastic tradition, veneration of the Christ Child and the representations of the Nativity were soon adapted to the private sphere.

The tradition of making three-dimensional recreations of the Nativity was particularly important in Naples, and the Museo di Certosa di San Martino houses the most significant and comprehensive collection of presepi in Italy. 5 The collection includes the more than life-size wooden figure dated to 1340 , showing the Virgin reclining after the birth of Christ. The statue was part of the commission of a crib for the Poor Clares in Naples made by Queen Sancia, the second wife of King Robert. Raised by her mother, Sclaramonda of Foix, in the spirit of devotion to St Francis, Sancia would have been particularly

4 Luciani R., Santa Maria Maggiore e Roma (Rome: 1996) 138-143.

5 Middione R., "La Sezione presepiale", in Spinosa N. - Muzii R. - Pezzullo A. (eds.), La Certosa e il museo di San Martino: Museo nazionale di San Martino (Naples: 2002) 75. 


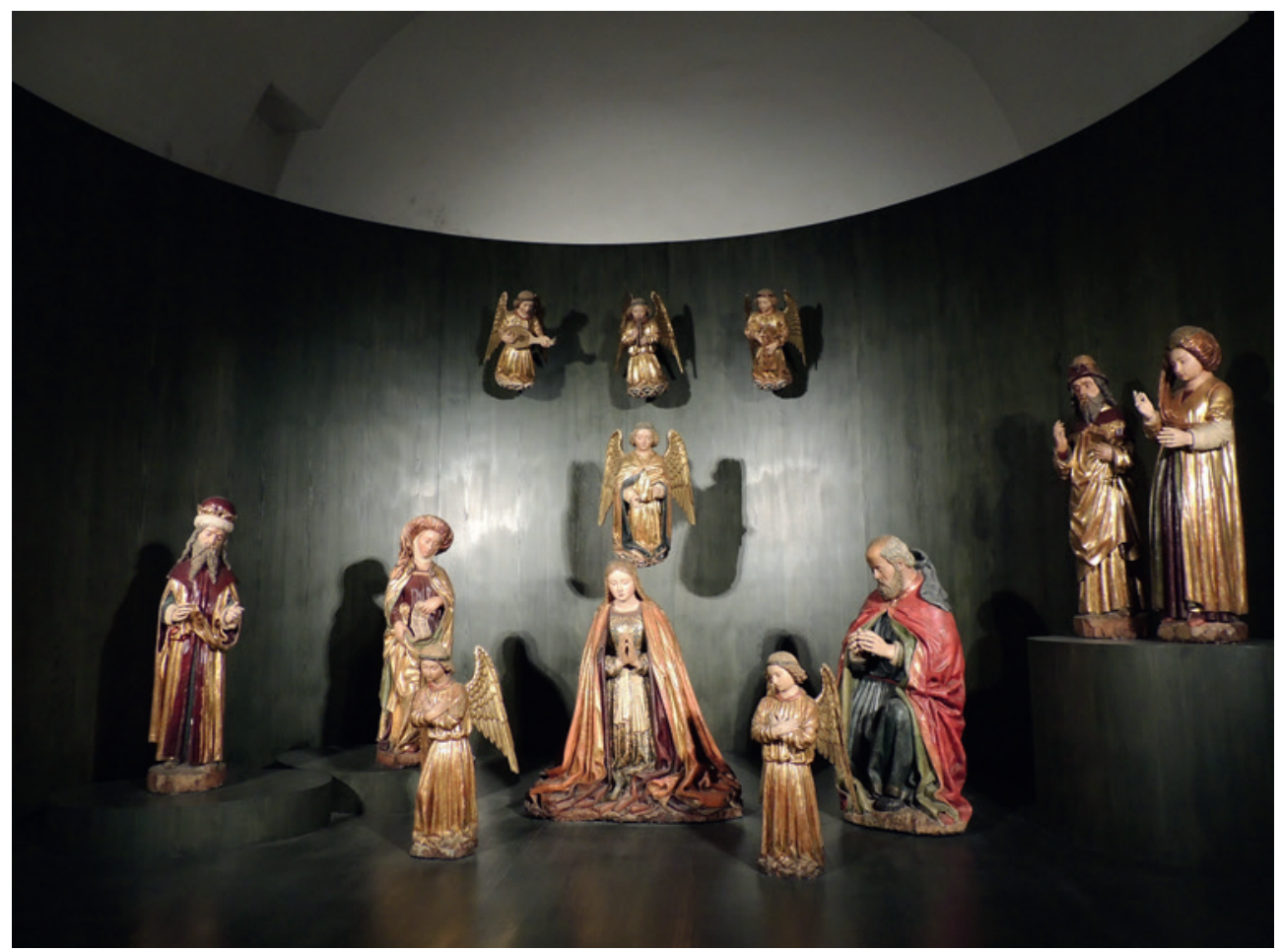

FIGURE 7.1 Pietro and Giovanni Alemanno, polychromy Francesco Felice, "Presepe”, 1478. Polychromed poplar wood. Naples, Museo di Certosa di San Martino PHOTOGRAPH BY THE AUTHOR

sensitive to sculptural representations of the Nativity. ${ }^{6}$ Another early presepe was made for the church of San Giovanni a Carbonara in 1478 by the sculptors Pietro and Giovanni Alemanno, who had previously been active in northern Italy. The scale of the undertaking was extraordinary as there were originally forty-one near-life-size figures carved in poplar wood and polychromed by Francesco Fiore. Only twelve figures from this ambitious scheme have survived and are now displayed in a vast purpose-designed niche in one of the rooms in the Museum of San Martino [Fig. 7.1].

In the late fifteenth century all major churches in the city had a chapel with a sculptural representation of the Nativity, including San Domenico Maggiore,

6 Musto R., "Queen Sancia and the Spiritual Franciscans", in Kirshner J. - Wemple S. (eds.), Women of the Medieval World: Essays in Honour of John H. Mundy (Oxford: 1985) 183; Bruzelius C., "Queen Sancia of Mallorca and the Convent Church of Sta. Chiara in Naples", Memoirs of the American Academy in Rome 40 (1995) 69-100. 
Santa Chiara, San Lorenzo Maggiore and Sant'Anna dei Lombardi. Later, in the first half of the sixteenth century, across the Italian peninsula new presep $i$ were commissioned both for institutional and domestic contexts. In Urbino ca. 156o, at the Oratory of St Joseph, the sculptor Federico Brandani (1523-1571) created a monumental presepe with life-size stucco figures. ${ }^{7}$ Such compositions were informed by the great importance placed on the devotion to the birth of Christ by the Franciscans.

Previous scholars have stressed the significance of figures of the Christ Child in the context of female spirituality. The cases of Italian mystics such as Camilla Battista da Varano have been used to explore how infant Jesus dolls shaped the relationship of women with the divine. ${ }^{8}$ Christiane Klapisch-Zuber wrote about the documented use of such dolls by Florentine elite women. ${ }^{9}$ Writing about Margaretha von Ebner, a German fourteenth-century mystic, Ulinka Rublack distinguished three kinds of interaction with a sculpted image of the Christ Child, namely physical contact, dialogue and meditation..$^{10}$ In a Florentine context, claims about interactions with figures of the Christ Child being a predominantly female activity seem to be confirmed by Savonarola's preaching against such practices:

Se tu odi dire la tale monaca del tale monasterio è una santa e tu sappia che la si diletti di avere libriccini dorati e bambini di gesso vestiti di seta, e che in cella la tenga di molte cose superflue, subito tu ti scandalizzi, e nel cuore tuo tu di': certo costei non è santa come si dice; donde ne seguita che gli è vero quello che io ho detto, che alla santità della vita seguita la semplicità. ${ }^{11}$

Zampetti P., Scultura nelle Marche dalle origini all'età contemporanea (Florence: 1993) 22.

8 For Camilla da Varano see Luzi P., Camilla Battista da Varano. Una religiosità fra papa Borgia e Lutero (Turin: 1989); Capriotti G., "Simulacri dell'invisibile. 'Cultura lignea' ed esigenze devozionali nella Camerino del Rinascimento", in Casciaro R. (ed.), Rinascimento scolpito. Maestri del legno tra Marche e Umbria, (Milan: 2006) 73-83; Catalogue entries for Virgin adoring the Child by Master of the Castello Nativity and The Christ Child attr. Domenico Indivini, M. Corry - Z. Sarnecka in Corry M. - Howard D. - Laven M. (eds.), Madonnas and Miracles: The Holy Home in Renaissance Italy (London: 2016) 92-93.

9 Klapisch-Zuber C., "Holy Dolls: Play and Piety in Quattrocento Florence", in Women, Family and Ritual in Renaissance Italy, trans. L. Cochrane (Chicago: 1985) 312-313.

10 Rublack U., "Female Spirituality and the Infant Jesus in Late Medieval Dominican Convents", in Scribner B. - Johnson T. (eds.), Popular Religion in Germany and Central Europe, 1400-1800 (Houndsmills-Basingstoke-London: 1996) 25.

11 'If you hear a nun from a nunnery called a saint and you learn that she delights in having gilded books or dolls in gesso clothed in silk, and that in her cell she keeps many superficial things, soon you will be shocked, and in your heart you will say: certainly she is not a saint as is said; from this can be inferred that what I said was true, that from the sanctity of life results simplicity'. Savonarola Girolamo, Sermoni e prediche, vol. 1 (Prato: 1846) 420. 
However, interaction with a three-dimensional figure of the Christ Child was by no means an exclusively female practice. ${ }^{12}$ Fra Franceschino from Cesena, the keeper of the Biblioteca Malatestiana, had in his camera: 'Uno bambino bia(n)cho de terra vedriada cum una spera in mano cum certi patrinostri al collo' ['The Christ Child in white glazed terracotta with a spera in his hand and some rosary beads around his neck'].13

From this description the figure from Franceschino's camera appears to be somewhat similar to the Christ Child modelled in Andrea della Robbia's workshop ca. 1500 [Fig. 7.2]. ${ }^{14}$ The glazed terracotta statuette of relatively small dimensions ( $45.7 \mathrm{~cm}$ high) might have been made for a domestic space. ${ }^{15}$ As pointed out by John Pope-Hennessy, there are no signs of it originally belonging to a bigger structure such as a tabernacle, and therefore it likely functioned as an independent three-dimensional statuette. ${ }^{16}$ The immaculate whiteness of the body of the Christ Child stands in dramatic contrast to the intense colour of the base, which evokes porphyry. The only two other colours used by the artists were brown for the eyes and green for a leaf, which serves as a rear support. This support, which allows the figure to stand, is not without significance for the sculpture's function. Wooden infant Jesus dolls have been said to fall into two categories: those which could not stand and therefore had to be laid in a crib or cradled in the arms, ${ }^{17}$ and those which could stand and perhaps encouraged more contemplative, physically detached interaction. ${ }^{18}$

In relation to a thirteenth-century figure (42 $\mathrm{cm}$ high) attributed to Ambrogio Lorenzetti, now in Berlin, Ursula Schlegel pointed out that the peculiar inclusion of the drapery under the Christ Child's feet indicated that the figure, depending on the occasion, could either stand or lie in a manger. ${ }^{19}$ The figure from the Della Robbia workshop has been previously discussed in

12 Richard Trexler described the use of these "sacred" dolls by children. See his Public Life in Renaissance Florence (Ithaca: 1980) 88.

13 Domeniconi A., "Un inventario relativo a un custode della Biblioteca Malatestiana: frate Franceschino da Cesena (1489)", Studi romagnoli 16 (1965) 185. Original inventory consulted in Archivio Notarile Mandamentale di Cesena, Atti di Novello Borelli, 18.08.1489 no. 108. It is possible that the object held by the Christ Child is in fact una sfera, a globe, which is his frequent attribute.

14 Pope-Hennessy J., Catalogue of Italian Sculpture in the Victoria and Albert Museum, vol. 1 (London: 1964) 225-226, cat. no. 217.

15 Catalogue entry for The Christ Child by the Workshop of Andrea della Robbia, Z. Sarnecka in Corry - Howard - Laven (eds.), Madonnas and Miracles 80-81.

16 Pope-Hennessy, Catalogue of Italian Sculpture 226.

17 Previtali G., "Il Bambin Gesù come immagine devozionale nella scultura italiana del Trecento", Paragone 21 (1970) 37.

18 Rublack, "Female Spirituality and the Infant Jesus" 23.

19 Schlegel U., "The Christ Child as Devotional Image in Medieval Italian Sculpture", The Art Bulletin $5^{2}(1970) 4$. 


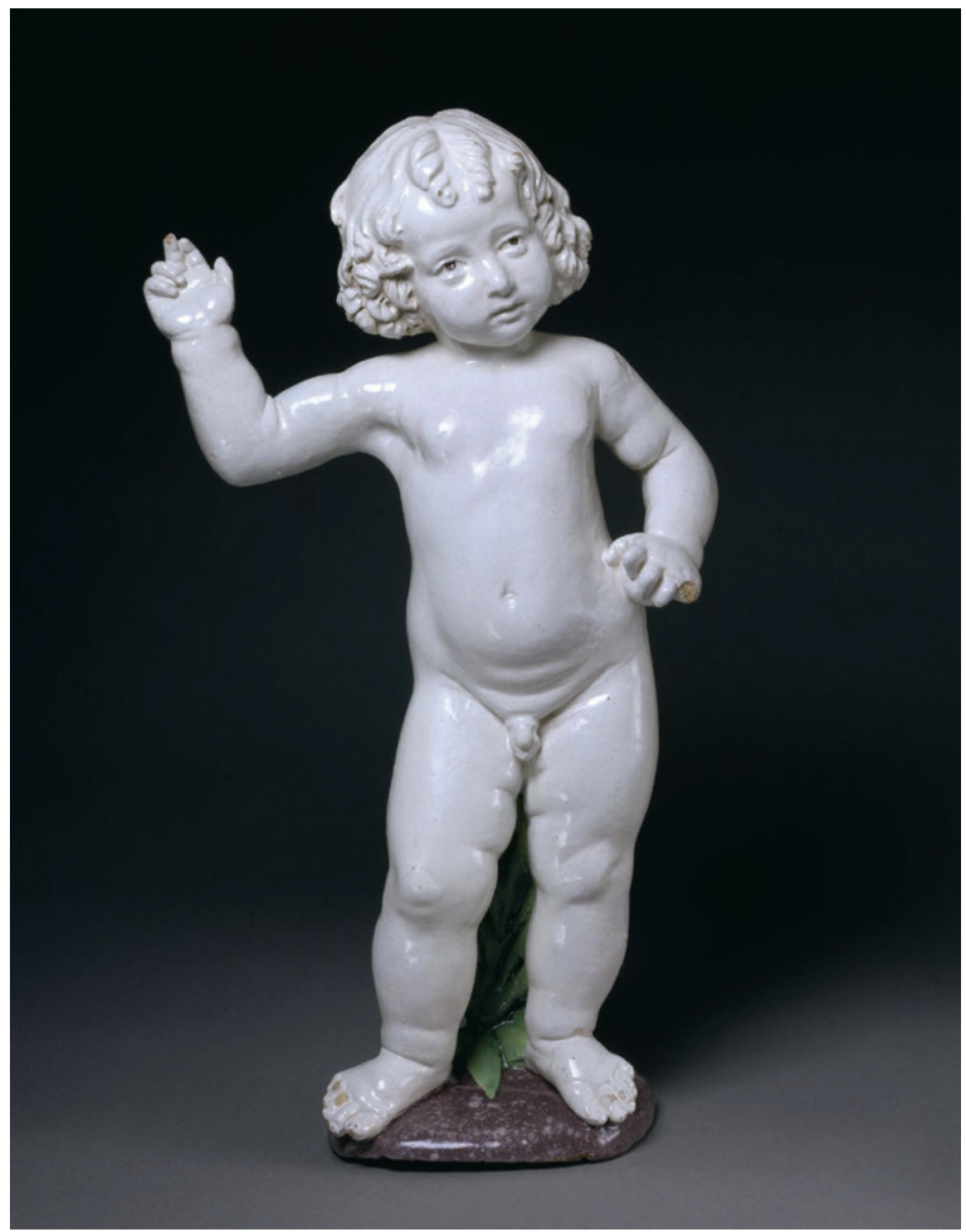

FIGURE 7.2 Andrea della Robbia's workshop, "Christ Child", ca. 1500. Glazed terracotta, h: $45.7 \mathrm{~cm}$. London, Victoria and Albert Museum (Inv. no. 7702-1861)

(C) VICTORIA AND ALBERT MUSEUM, LONDON 
relation to brides, who would receive similar objects 'as part of their marital goods'. ${ }^{20}$ However, in the light of Fra Franceschino's inventory this hypothesis needs to be nuanced, and potential male ownership considered. A male owner could have handled and interacted with the Christ Child figure in much the same way as a woman, but more research needs to be done on the nature of such interactions. Literary sources, such as Teofilo Folengo's La Palermitana, describe how in the early sixteenth century friars would re-enact the Nativity. ${ }^{21}$ After his experience of sacra rappresentazione in Palestine, Folengo imagined that he himself held Christ Child in his arms. ${ }^{22}$ In so doing he mirrored Saint Francis and the Christmas Eve mass at Greccio.

It could be argued that the sculpted figures of the Christ Child should be linked predominantly to female and male convents. However, the iconography connected with the Nativity was certainly also present in lay houses, as is documented by a Neapolitan inventory. According to a document dated 14th July 1485, Alberico de Balbiano, Conte di Lugo di Cuneo, owned a presepe. Among various other possessions, the inventory lists: 'una cona de gesso colla figura de la Vergene Maria. Item un altra cona collo presepio de nostro Segnore', ['a work in gesso with a figure of the Virgin Mary. Another work with the Nativity of Our Lord']. ${ }^{23}$

Alberico's residence was on Piazza di Nido, which perhaps could account for a particular devotion to the image of the Nativity due to the proximity of the church of Santa Maria del Presepe located on the same square. This inventory is important for its confirmation that already towards the end of the fifteenth century the imagery of the Nativity was present in domestic space. The text has come down to us in a transcription made by Gaetano Filangieri from the original fifteenth-century document, which was destroyed in the fire at the Neapolitan archives during the Second World War. ${ }^{24}$ From the wording of the inventory it is impossible to infer whether the altarpiece was sculpted, but perhaps the fact that the two objects follow each other in the document could indicate their formal similarity.

The word 'ancona', or its shortened form 'cona', has its origins in the Greek word for image - 'eikona' and is typically used to describe a sacred image

\footnotetext{
20 Musacchio J.M., "Conception and Birth", in Ajmar-Wollheim M. - Dennis F. (eds.), At Home in Renaissance Italy, exh. cat. Victoria and Albert Museum (London: 2006) 130.

21 Folengo Teofilo, "La Palermitana", in Renda U. (ed.), Opere italiane, vol. 3 (Bari: 1914) $119-122$.

22 I am very grateful to Dr Marco Faini for this reference.

23 Archivio Filangieri, Naples Busta 46, notary Cesare Malfitano Protocolli 1484-85, fol. 276.

24 On the losses from the Neapolitan archives see Belli C., "Il fondo notarile quattrocentesco dell'archivio di stato di Napoli", Napoli Nobilissima 60 (1994) 195-202.
} 
painted on a panel or canvas, or carved in relief, and destined to be placed on an altar. ${ }^{25}$ Indeed in some Neapolitan inventories the word 'ancona' seems to be interchangeable with the word 'image', but in many instances the word 'image' or 'figura' followed 'cona', which consequently seems to be a broader term. Recently, Chriscinda Henry, in considering the term 'quadro' as used in Venetian archival materials, has argued that this term was used not only to describe a painting but also a print or a wooden or terracotta relief. ${ }^{26}$ This seems also to have been the case with the domestic 'ancone' in Renaissance Naples, which could be either sculpted or painted. ${ }^{27}$ Whether a sculpted relief or a painted scene depicting the Virgin adoring the Christ Child, the object recorded in Alberico's house proves that large-scale wooden and terracotta representations of the Nativity were translated into smaller-scale, domestic objects with the same iconography.

In the first half of the sixteenth century we find entries in inventories which make specific reference to the presence of three-dimensional presep $i$ in private residences in other parts of Italy. One such object is described in a list of possessions compiled in 1532 in Pesaro, in the house of Bastianus Semi. The inventory lists: 'Item doe madonne et uno presepio con proprio panisello' ['Two Madonnas and a crib with its drapery']. ${ }^{28}$ The name of the cloth 'panisello' or 'pannicello', could have been a reference to a material used for covering the 'presepio' or as robes for the Christ Child. ${ }^{29}$ What is striking about this brief description is the presence of two figures of the Virgin, which could suggest a narrative involved in the representation, perhaps with the depiction of the Virgin seated with her divine Son and another of her kneeling and adoring him in prayer.

We find a similar repetition of a figure, this time of the Christ Child, in a maiolica representation of the Nativity from the Fitzwilliam Museum in Cambridge, which shows two episodes described in the Gospels: the Annunciation to the Shepherds (Luke, 2: 8-18) and the Adoration of the Magi (Matthew, 2: 9-12). ${ }^{30}$

25 Battaglia S., Grande dizionario della lingua italiana, vol. 1 (Turin: 1961-2009) 447.

26 Henry C., "What Makes a Picture? Evidence from Sixteenth-Century Venetian Property Inventories", Journal of the History of Collections 23/2 (2011) 253-265.

27 To give just a few examples, in an inventory of a house of Simone de' Guerrieri from 1497 there is a 'cona de gesso cum Vergine Maria' and a 'cona piczula cum figura Virginis Marie de argento'. In another inventory from 1478 in a chamber of the house of Andrea del Ponte there was a 'conam unam cum figura Virginis Marie et certorum angelorum'.

28 Archivio di Stato di Pesaro, Fondo Notarile, Notaio Germani Giovanbattista, vol. 364 (1532-1533), fol. 662r.

29 Treccani. Vocabolario della lingua italiana (Rome: 1987-1994) 658.

30 Poole J.E., Italian Maiolica and Incised Slipware in the Fitzwilliam Museum Cambridge (Cambridge: 1995) 244-245. 


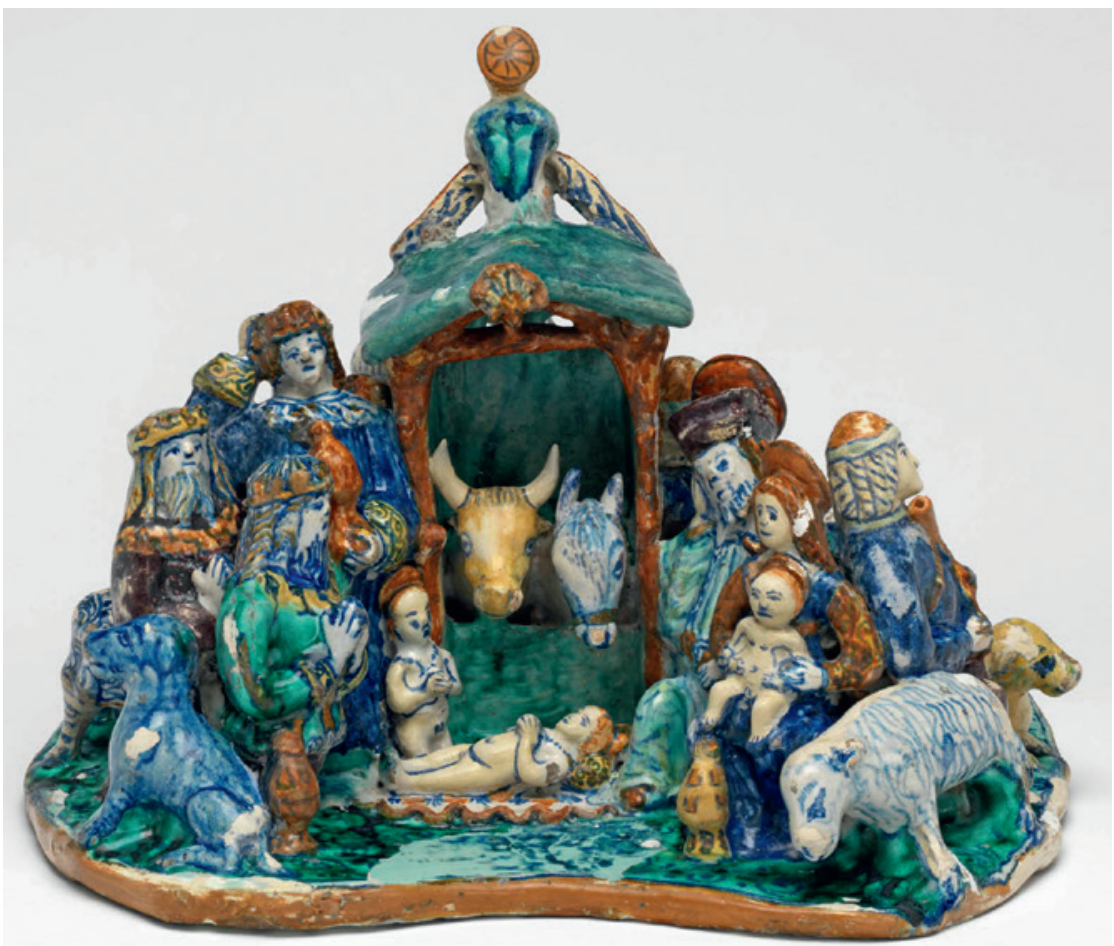

FIgURE 7.3 Giovanni di Nicola di Manzoni di Colle (?), "The Adoration of the Magi", ca. 1509-1515. Glazed terracotta, $25.5 \times 34.5 \mathrm{~cm}$. Cambridge, Fitzwilliam Museum (Inv. no. C.2180-1928)

(C) FITZWILLIAM MUSEUM, CAMBRIDGE

The object was clearly intended to be viewed from all angles and each side offers interesting details. Despite its considerable weight (6.2 kg, or $13.7 \mathrm{lbs})$ the piece welcomes physical interaction, and would perhaps have been contemplated whilst the head of the household narrated the sacred history. The narrative character of the representation is communicated through the figure of the Christ Child, who, in the scene of the Adoration of the Magi, is depicted seated on the Virgin's lap, and then appears again on a cloth in a manger whilst being adored by the Wise Men [Fig. 7.3]. ${ }^{31}$

31 Catalogue entry for The Annunciation to the Shepherds and The Adoration of the Magi, attr. to Giovanni di Nicola di Manzoni of Colle, Z. Sarnecka in Corry - Howard - Laven (eds.), Madonnas and Miracles 22-23. 
The iconography of the Nativity appeared most consistently in domestic space on maiolica figures such as inkstands, which survive in large numbers. ${ }^{32}$ They include figures of the Virgin, St Joseph and the Christ Child in a crib attended by an ass and ox. They often have a place for a coat of arms, to record the family's name and to assert the owner's devotion. ${ }^{33}$ We know from an archival record that in 1508 Piero Soderini, the strongest opponent to the Medici, and first Chancellor of the Florentine Republic, ordered the destruction of all objects with coat of arms of the exiled Medici family, both in potters' workshops and in private houses. ${ }^{34}$ This illustrates an established practice of including the arms of powerful families on pottery. Perhaps the seemingly scratched out space of the coat of arms on the calamaio from the Museum Ariana in Geneva points to the infamy of the family whose stemma once decorated the object [Fig. 7.4]. In other instances, the place for the coat of arms on maiolica nativity inkstands may have been left deliberately empty for marketing purposes, as in another example from Victoria and Albert Museum [Fig. 7.5]. These objects were made from moulds, which allowed for easy and fast reproduction. ${ }^{35}$ Therefore, one can imagine that the personalisation of the object occurred at the final stage with the coat of arms painted in cold polychromy on the surface of white glaze. The stemma would therefore be the least durable part of the inkstand's decoration.

In the Museo Duca di Martina in Naples there is another calamaio with a scene of the Nativity [Fig. 7.6] ${ }^{36}$ It has been dated to ca. 1509 by Luciana Arbace

32 Piccini A., "I calamai dei Manzoni", Fimantiquari Arte Viva 30 (2002) 37-51; Marini M., in Wilson T. - Sani E. (eds.), Le maioliche rinascimentali nelle collezioni della Fondazione Cassa di Risparmio di Perugia, vol. 2 (Città di Castello: 2007) 54-65, cat. no. 23. Other religious and non-religious subject matter can be found on inkstands, for instance the ambitious inkstand with St George and the Dragon (inv. 26.420) now in the Corcoran Gallery of Art, or another inkstand with a sleeping knight (inv. 26.415) in the same collection. See Watson W., Italian Renaissance Maiolica from the William A. Clark Collection (London: 1986) 38-41.

33 This practice is also well-documented in the production of domestic glazed terracotta reliefs from the Della Robbia workshop. Giovanni della Robbia received three florins for reliefs of the Virgin and Child which included the arms of specific patrons. See Santi B., "Una bottega per il commercio. Repertori, vendite, esportazioni", in Gentilini G., I Della Robbia e l"arte nuova" della scultura invetriata (Florence: 1998) 88, n. 8.

34 Spallanzani M., Ceramiche alla Corte dei Medicinel Cinquecento (Modena: 1994) 142, document no. 3 .

35 For images of excavated plaster moulds for inkstands from Montelupo see Berti F., Storia della ceramica di Montelupo (Montelupo: 1997-2003) vol. 3, figs. 78-79.

36 The same model as the one used in the calamaio from the collection of the Duca di Martina was repeated in similar objects found in the following museums and collections: in the Guicciardini Corsi Salviati collection (dated 1507); in Sèvres (dated 1509); in the Museo di Faenza; in the Ariana Museum in Geneva; in the Giulianini collection 


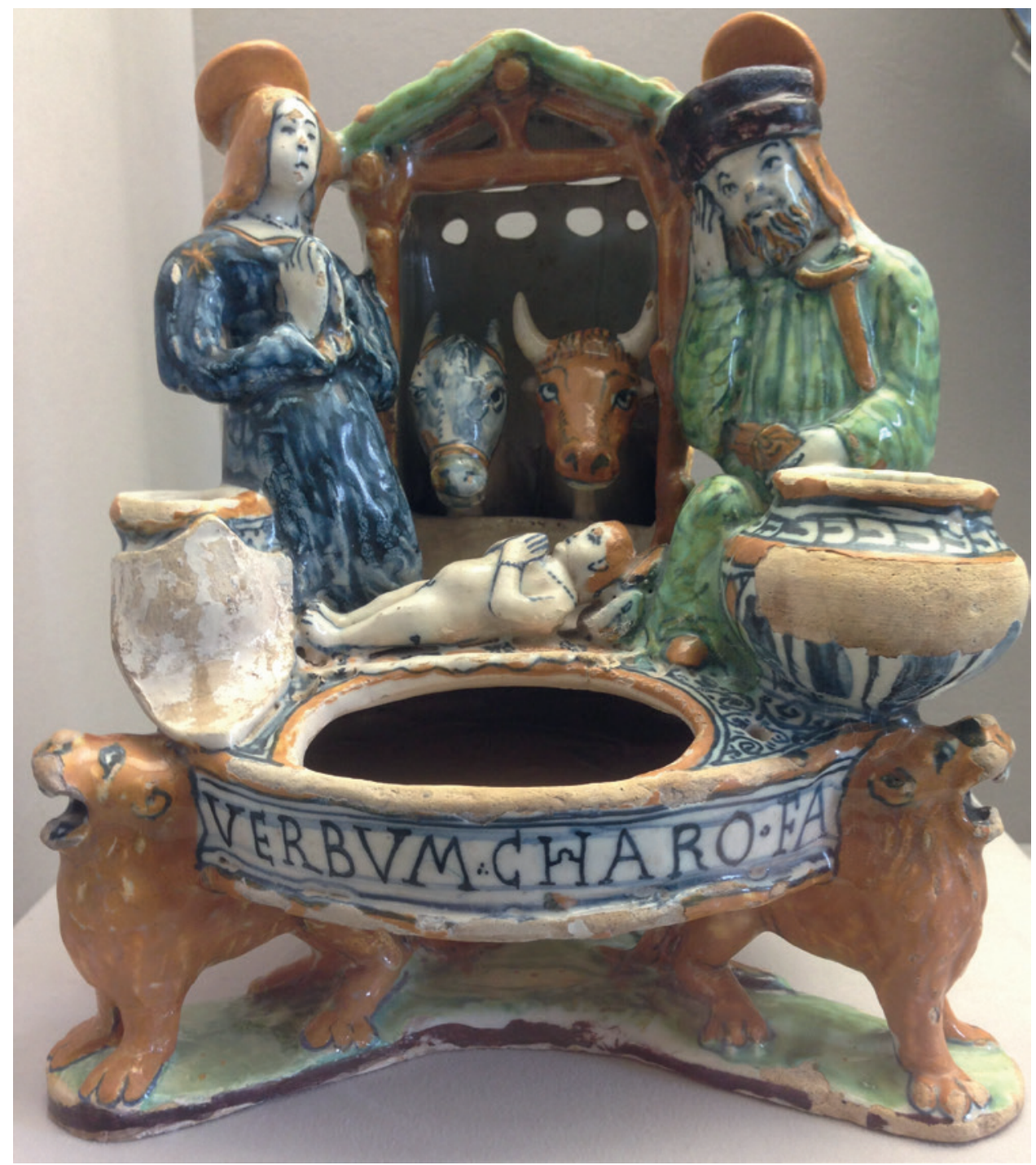

FIGURE 7.4 Giovanni di Nicola di Manzoni (?), "Nativity Inkstand", ca. 1509. Glazed terracotta, $24 \times 23 \times 22 \mathrm{~cm}$. Geneva, Museum Ariana (Inv. AR 4092) PHOTOGRAPH BY THE AUTHOR 


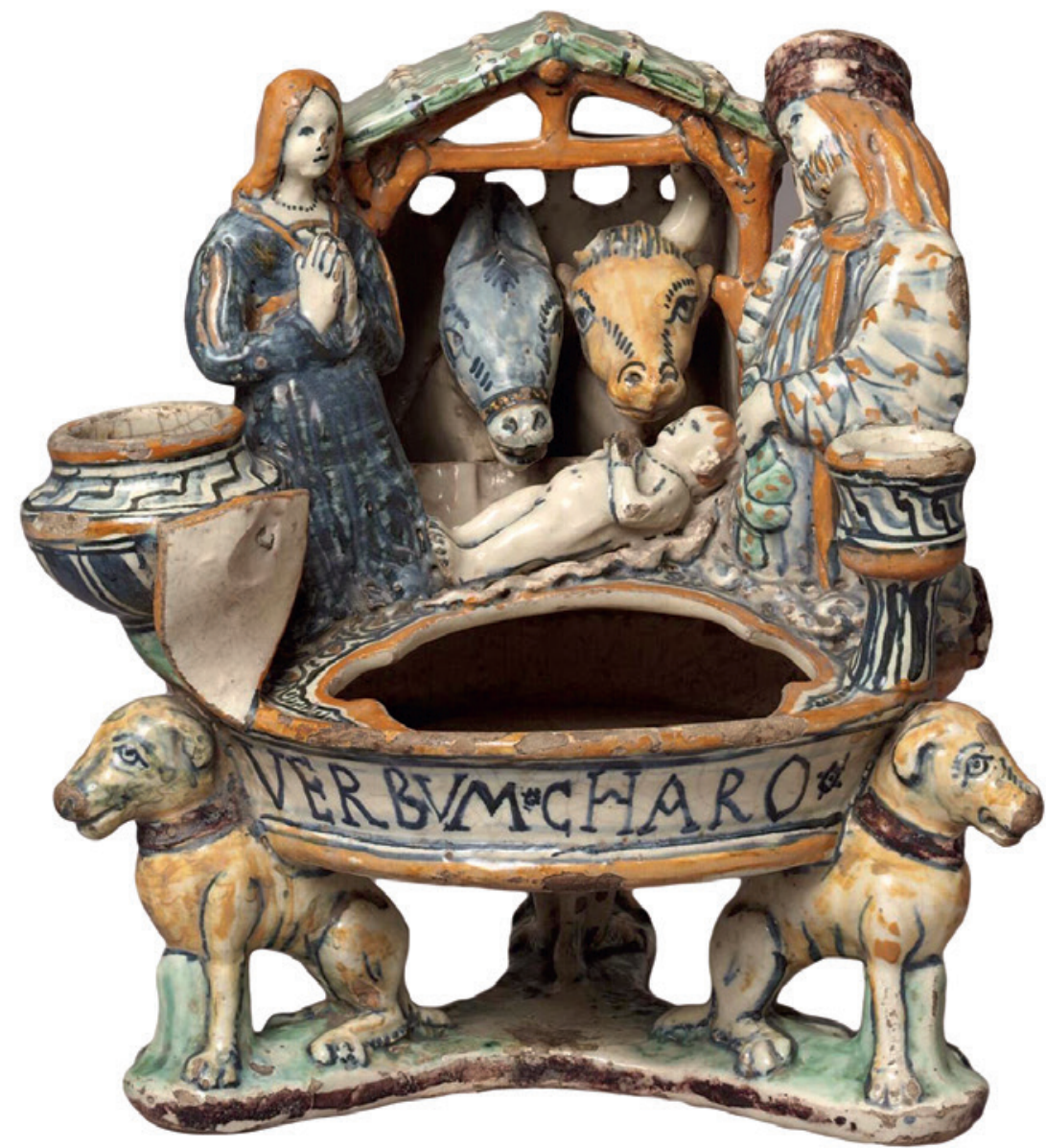

FIGURE 7.5 Giovanni di Nicola di Manzoni (?), "Nativity Inkstand", ca. 1509. Glazed terracotta, $24.4 \times 23.4 \times 22.2 \mathrm{~cm}$. London, Victoria and Albert Museum (Inv. no. 396-1889)

(C) VICTORIA AND ALBERT MUSEUM, LONDON

on the basis of stylistic similarities with a dated inkstand from the Ariana Museum in Geneva, and with a similar object in a private collection in London, dated $1510 .{ }^{37}$ The entire composition is raised on three lions, which was a

(dated 1509); in a private collection in London (sold at Sotheby's London, 20 March 1973, lot 17, dated 1510); in the Victoria and Albert Museum; in the Fitzwilliam Museum; in the Museum of Applied Arts in Budapest; and an example formerly in Beresford Hope collection (sold at Christie's 1 July 1985, lot 265).

Arbace L., La maiolica italiana (Naples: 1996) 25. 


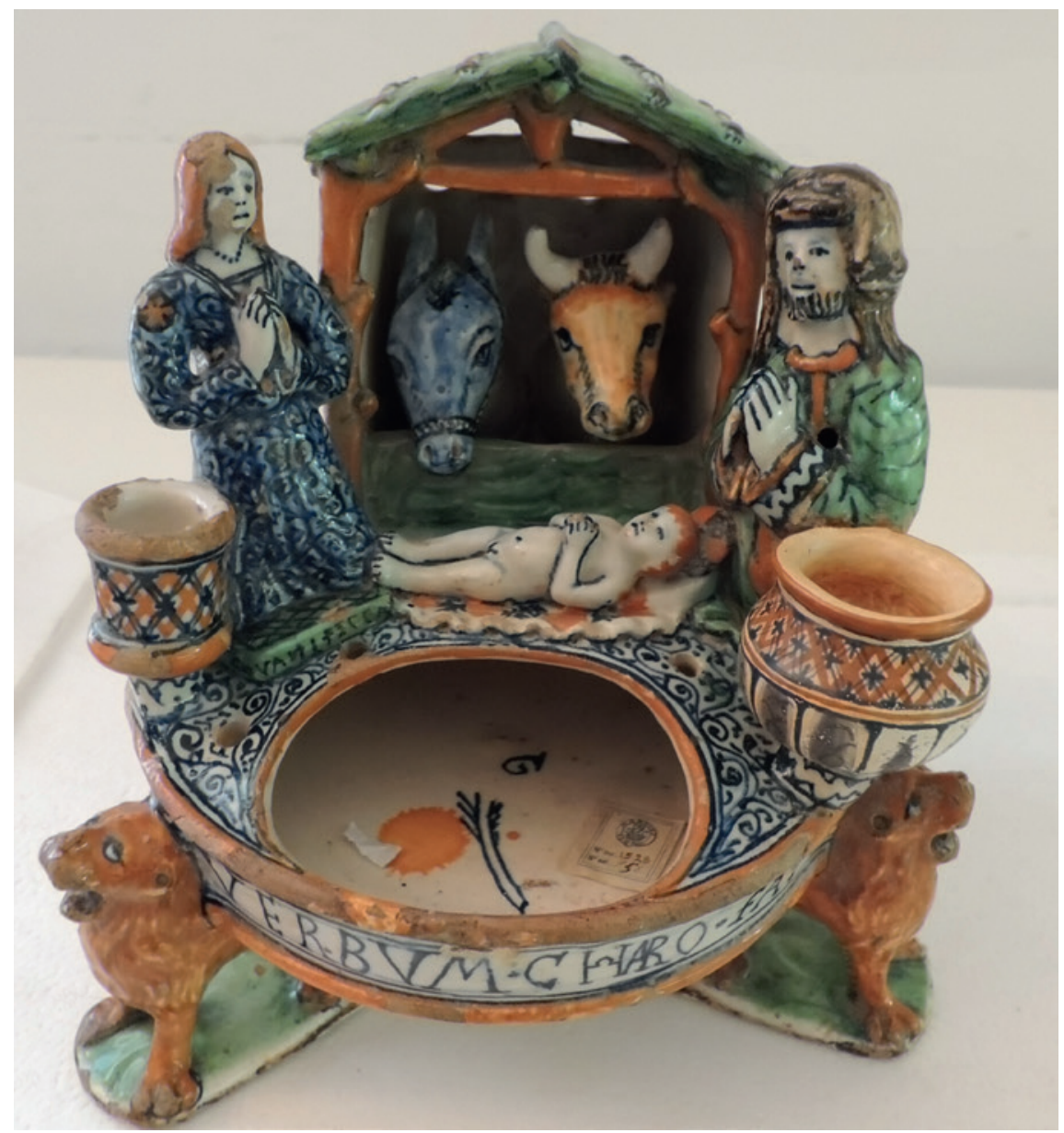

FIGURE 7.6 Giovanni di Nicola di Manzoni (?), “Nativity Inkstand”, ca. 1509. Glazed teracotta, $24 \times 23 \times 23 \mathrm{~cm}$. Naples, Museo Duca di Martina (Inv. no. 958) PHOTOGRAPH BY THE AUTHOR

common decorative form for the base of domestic objects, seen for instance in a fifteenth-century fruttiera made in Città di Castello, now in the Louvre. ${ }^{38}$ The figures are flanked by two cylindrical vase-like containers, perhaps for pens or to be used as candle sockets. A place for a candle would be useful both for illumination whilst writing and for producing wax for sealing letters. The inkwell contains the mark of the maker and the signature 'Giovani Fecea' on the cushion on which the Virgin kneels. On the basis of archival finds the artist has been identified as Giovanni di Nicola di Manzoni, a potter with a workshop

38 Del Vita A., "Le maioliche della collezione Carrand", Bollettino d'Arte 10 (1924) 436. 
in Colle Val d'Elsa, some twelve miles from Siena, a centre renowned for its ceramics production. ${ }^{39}$

The theme of the Nativity, the arrival in the world of the true logos, was particularly suitable for the decoration of this indispensable writing tool. According to an unpublished inventory from 1531, a notary from Monte Santo had among his private possessions: 'una fontana de terra in vaso con una madona in cima con larmo de Papa' ['a glazed terracotta inkstand with the Virgin and the papal coat of arms at the top']. ${ }^{40}$ The Virgin as the Mother of God could have acted as a patron of the written word, because, as the inscription included on many of these inkstands clearly states, it was from her that 'the Word was made flesh': 'Verbum charo factum est de Virgine Maria'. St Augustine in his writing about the Incarnation stressed that through the Virgin, from whom Christ took his physicality, human nature became sanctified and purified, and restored to its original condition, thus enabling the salvation..$^{41}$ The phrase on the inkstands partially quotes a passage from the Gospel according to St John 1:14 'Verbum caro factum est', which continues 'et habitavit in nobis', and not as on the inkstands 'de Virgine Maria'. The text is thus transformed and to it is added that the Word was made flesh from the Virgin Mary; moreover, an exaltation of the Mother of God is included with the words 'Ave Maria Gratia', which come from the greeting of the angel at the moment of the Annunciation. The inscription, as painted on the surface of this and other similar inkstands, stresses the glory of the Virgin as the Mother of God, rather than focusing solely on the Incarnation. Interestingly, the crucial word caro in all surviving inkstands of this type is spelled with 'ch' instead of 'c'. The fact that this additional ' $\mathrm{h}$ ' is the most decorative and the widest of letters in the inscription seems significant. In fact, in the inkstand from Naples, the letter ' $\mathrm{h}$ ' is so prominent that the artist omitted the letter ' $t$ ' in the word 'factum' and moved the final letter ' $m$ ' to the back of the calamaio.

The text on the inkstand 'Verbum Charo $\mathrm{Fa}$ [c]tum est de Virgine Maria', could be linked to a popular hymn 'In hoc anni circulo', which existed in multiple versions. ${ }^{42}$ The hymn, first published in 1582 in Piae Cantiones in Greifswald, Germany, has a refrain with exactly the same text 'Verbum Caro Factum est de Virgine Maria'. The earliest version of the hymn is in a manuscript

39 Marini M., Le maioliche rinascimentali $63,65$.

40 Archivio di Stato di Macerata, Notarile di Monte Santo, Notaio Giacomo Adriani, vol. 197, fol. 19r, 1st January 1531.

41 Verdon T., Maria nell'arte europea (Milan: 2004) 61-64.

42 Julian J., Dictionary of Hymnology (London: 1907) 1216-1217. 
version dated to the twelfth century, ${ }^{43}$ now in the Bibliothèque Nationale de France (Lat. 1139, f. 48r). ${ }^{44}$ This version, which is partly in Latin and partly in Provençal, contains the phrase 'de Virgine Maria' in the first stanza: 'In hoc anni circulo, vita datur saeculo, nato nobis parvulo De Virgine Maria'45 The late thirteenth-century Antiphonary of Bangor, Cod. Tauriensis, F I 4 (now in the Biblioteca Ambrosiana, Milan), includes in the refrain of the same hymn the entire phrase as it appears on the maiolica inkstands. ${ }^{46}$ Evidently, the text circulated in Italy long before the second half of the sixteenth century.

The use of music in individual prayers deserves further attention in Italian Renaissance studies. ${ }^{47}$ The similar presence of songs and musical notes can be observed in glazed terracotta representations of the Nativity from the Della Robbia workshop. Luca della Robbia's relief from the Museum of Fine Arts in Boston [Fig. 7.7] includes musical notes and the opening line of the Gloria in Excelsis Deo. ${ }^{48}$ The music is not a product of an artistic fantasy but a real piece of music, in this case the standard plainchant intonation for the Gloria section of the Mass. ${ }^{49}$ Even though there are no musical notes on any of the published maiolica inkstands, it could be argued that the music which accompanied the text was widely disseminated and it can be assumed that users of the inkstand could have sung the lines without being reminded of the notes. Music was inextricably linked with the devotion to the crib and the friars depicted in the fresco of the Mass in Greccio in the Upper Church in Assisi are depicted singing. Thus, through the agency of these inkstands liturgical music might have permeated the home and the sounds from the ecclesiastical space informed and spiritually enriched everyday domestic space. That the music was implicit in the maiolica inkstands is further confirmed by the presence of various musical instruments held by shepherds in several versions of the Nativity maiolica sculpture. Moreover, in the catalogue of maiolica from the Bargello in Florence

43 Some scholars think that the text of the hymn might be as early as the late eleventh century. See Haines J., Medieval Song in Romance Languages (Cambridge: 2010) 214-215.

44 Du Méril E., Poésies inédites du Moyen Âge (Paris: 1854) 337-338, n. 6.

45 Ibid., 337, n. 6.

46 Dreves G.M., Analecta Hymnica Medii Aevi, 20 (Leipzig: 1895) 22.

47 Dennis F., "Scattered Knives and Dismembered Song: Cutlery, Music and the Rituals of Dining", Renaissance Studies 24/1 (2010) 156-184. On communal singing in religious contexts see Macey P., "Singing in and Around Florence Cathedral Oral and Written Local and Imported Traditions", in Radke G.M. (ed.), Make a Joyful Noise: Renaissance Art and Music at Florence Cathedral (Atlanta: 2015) 63-71.

48 For further discussion of this relief see Sarnecka Z., "Luca della Robbia and his Books. The Renaissance Artist as a Devotee”, Artibus et Historiae 74 (2016) 297.

49 I am very grateful to Professor Iain Fenlon for his help with the musical aspect of my research. 


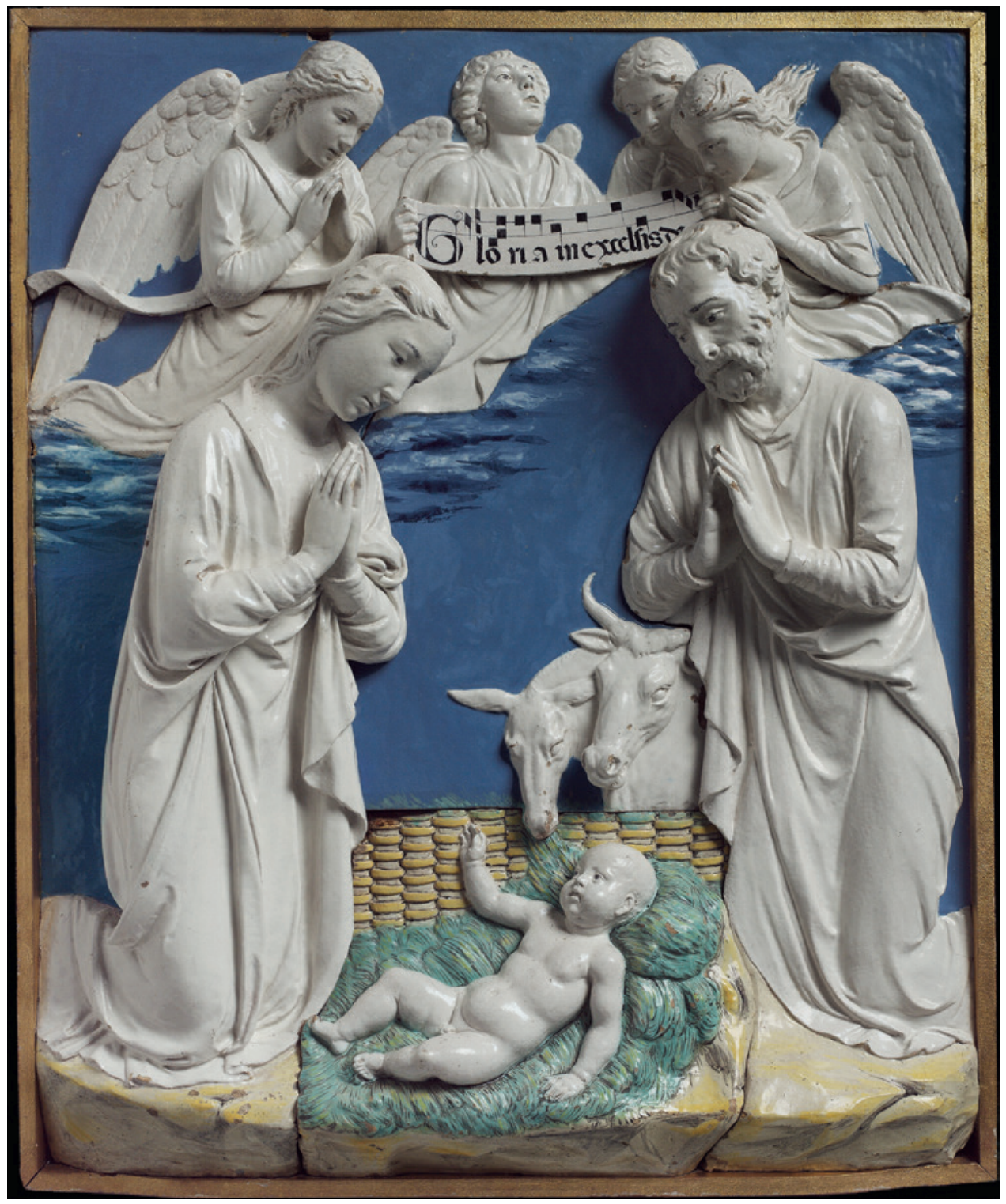

FIGURE 7.7 Luca della Robbia, "Nativity with Gloria in Excelsis", ca. 1470. Glazed terracotta, $88.9 \times 73.7 \mathrm{~cm}$. Boston, Museum of Fine Arts (Inv. no. 17.1463) (C) MUSEUM OF FINE ARTS, BOSTON 


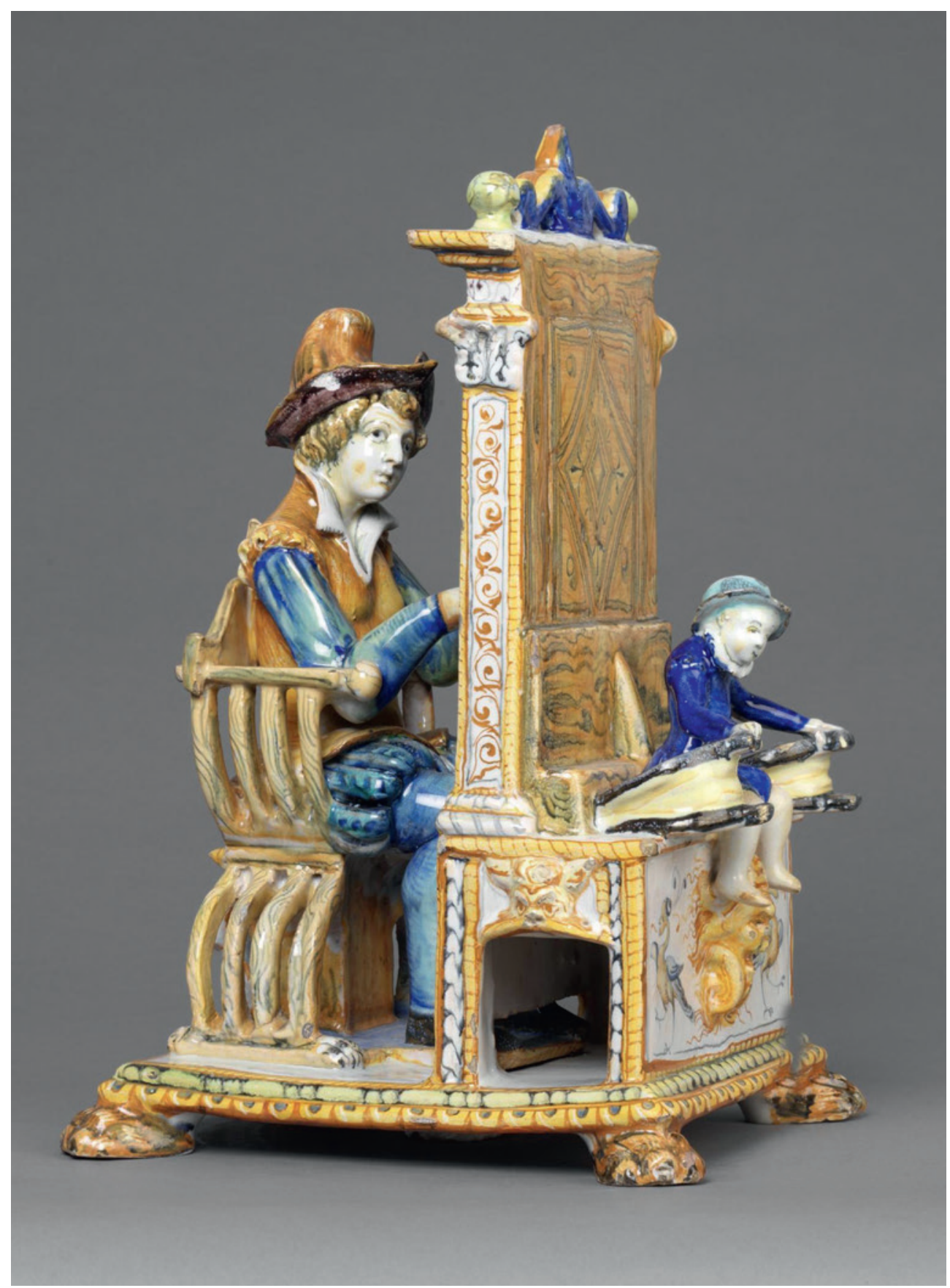

FIGURE 7.8 Fontana Family Workshop, "Inkstand with a Man Playing an Organ”, ca. 1580.

Glazed terracotta, $38 \times 27 \times 22 \mathrm{~cm}$. London, Victoria and Albert Museum

(Inv. no. 8400-1863)

(C) VICTORIA AND ALBERT MUSEUM, LONDON 


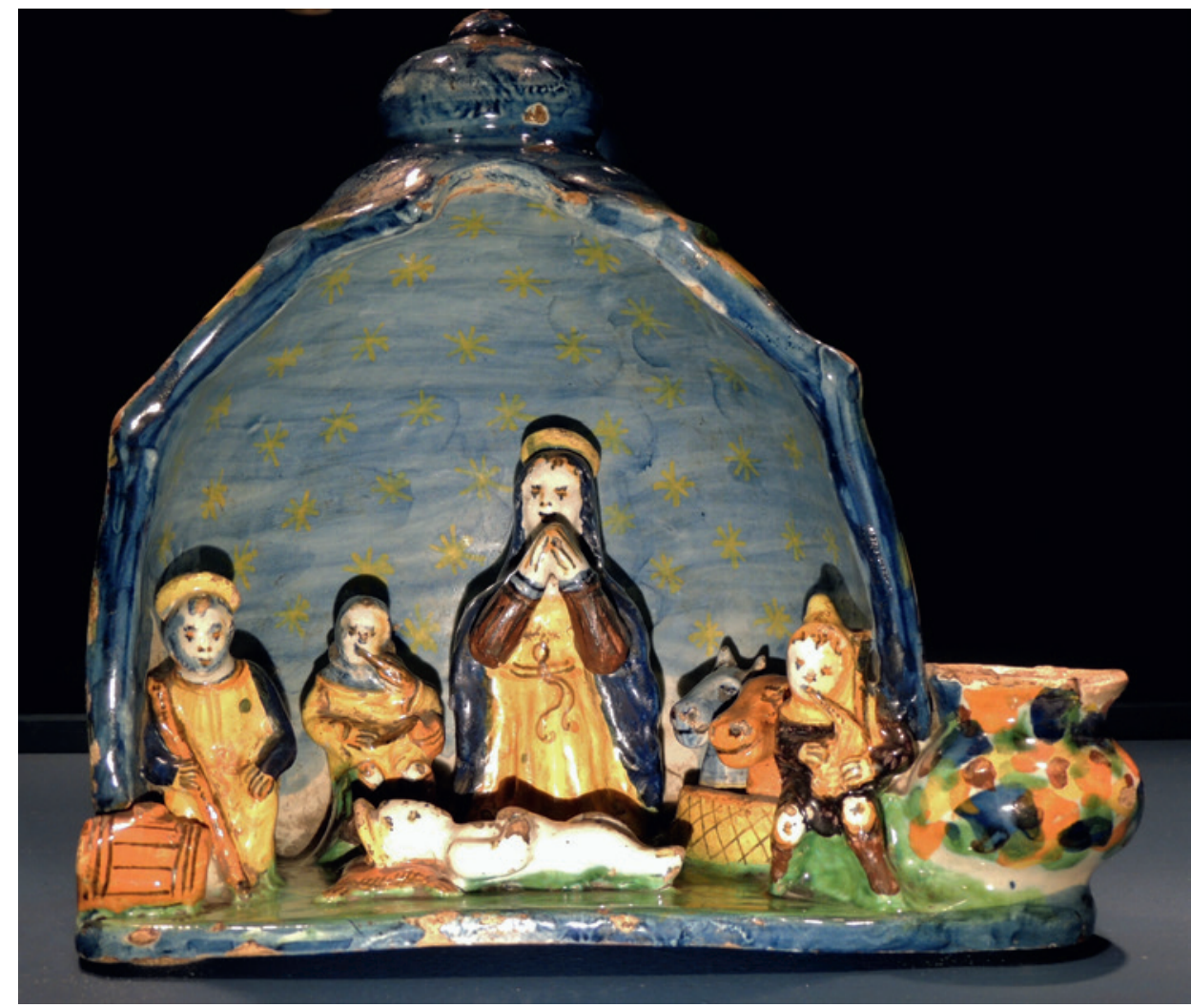

Figure 7.9 Anonymous Artist from Faenza (?), "Inkstand with Crib scene", first half of the 16 th century. Glazed terracotta, $22.5 \times 14 \mathrm{~cm}$. Cento, Private collection PHOTOGRAPH BY THE AUTHOR

there is an inkstand made in Urbino ca. 1570 in the form of organs with music making angels. ${ }^{50}$ The object is of similarly small dimensions to the Nativity inkstands (40 cm high), and is painted in bright colours: blue, orange, yellow and green. From around the same time and also from Urbino, from the Fontana family workshop [Fig. 7.8], comes another inkstand with a man playing an organ, now in the V\&A Museum. ${ }^{51}$ The existence of similar forms shows that maiolica inkstands were particularly suitable for making reference to music

5o Conti G., Catalogo delle maioliche di Museo Nazionale di Firenze. Palazzo di Bargello (Florence: 1971) cat. no. 196.

51 Paolinelli C., "Calamaio", in Giannotti A. - Pizzorusso C. (eds.), Federico Barocci 1535-1612. L'incanto del colore. Una lezione per due secoli (Cinisello Balsamo: 2009) 401; Sani E., Italian Renaissance Maiolica (London: 2012) 156 fig. 180. 
either through the representation of instruments or through the inclusion of text which circulated most widely in a sung form.

The model which was repeated in so many versions is not the only example of an inkstand with the Nativity scene. A private collection in Cento, near Bologna, houses a Calamaio con presepe, which was probably made in Faenza in the first half of the sixteenth century. ${ }^{52}$ It is again of small dimensions $(22.5 \mathrm{~cm}$ high $)$, and could have been destined for a domestic space. However, the typical stable is here substituted by a celestial vault with stars on the inside and trees on the outside of the cupola encompassing the figures [Fig. 7.9]. Unlike in other inkstands, the Virgin - glorified as the Mother of God - is placed at the centre of the composition and is much bigger than the other figures. Alongside St Joseph and the Christ Child, and the traditional ox and ass, there are two figures of shepherds who are both playing bagpipes. As has been pointed out, the setting for the figures is a cross-section of an upturned vase, perhaps proving that similar inkstands with Nativity scenes were made as a side-line production in an average potter's workshop..$^{53}$ However, this inkstand does not lack imaginative details, proving a certain level of artistic skill, such as a shepherd on the right hand side who protrudes into the space of the viewer, or a barrel on the left which balances the composition.

The close analysis of surviving sculptural examples of presepi provides information about the religious practices these objects encouraged. Dissemination of this iconography is most visible in Naples, where the tradition of presepi, both in ecclesiastical and domestic space, has flourished uninterruptedly from the thirteenth century until the present day. Outside the church of San Gregorio Armeno heaps of small-scale, affordable figurines in painted terracotta are still sold for domestic recreations of the Nativity. Those sculptural objects displayed within a home, either in the form of a single statuette of the Christ Child or more elaborate Nativity scenes on inkstands, made manifest St Francis's desire to visualise the mystery of God Incarnate. In the context of the home, they could have been used as a powerful visualisation of the sacred narrative as it was read out loud by the paterfamilias, or acted as lively reminders which prompted people to enact their daily devotions. Moreover, maiolica inkstands with three-dimensional representations of the Nativity often included inscriptions which circulated most widely in a sung form. Thus they seem to have encouraged the celebration of the Nativity through pious singing - the

52 Paolinelli C. (ed.), Lacrime di smalto. Plastiche maiolicate tra Marche e Romagna nell'età del Rinascimento (Ancona: 2014) 114, ill. 115.

53 Paolinelli, Lacrime di smalto 114. 
tradition initiated at the Mass at Greccio. They have been previously discussed in relation to scholars' studioli, as art objects designed to be used as writing tools and for the display of the head of the household's erudition. ${ }^{54}$ However, as demonstrated in this essay, one needs to remember that they also responded to the tradition of three-dimensional presepi in churches and that they satisfied the need to share the joy of the Incarnation in a domestic environment.

\section{Bibliography}

Arbace L., La maiolica italiana (Naples: 1996).

Balla G. - Jékely Z., The Dowry of Beatrice. Italian Maiolica Art and the Court of King Matthias (Budapest: 2008).

Berti F., Storia della ceramica di Montelupo (Montelupo: 1997-2003).

Brooke R., The Image of St Francis (Cambridge: 2006).

Celano Thomas de, Vita prima S. Francisci Assisiensis et eiusdem legenda ad usum chori (Rome: 1926).

Cserey E., "Di un calamaio in maiolica del Rinascimento al Museo della Arti Applicate di Budapest", Faenza 61, 4-5 (1975) 86-93.

Frugoni Ch., "Sul Natale di Greccio e le sue rappresentazioni", in Frugoni Ch. - Siddi F. (eds.), Il mistero gioioso. Il presepe di Greccio e le sculture del Gesù Bambino benedicente (Siena: 2012) 11-31.

Klapisch-Zuber C., "Holy Dolls: Play and Piety in Quattrocento Florence", in Women, Family and Ritual in Renaissance Italy, trans. L. Cochrane (Chicago: 1985) 310-329.

Luzi P., Camilla Battista da Varano. Una religiosità fra papa Borgia e Lutero (Turin: 1989). Marini M., in Wilson T. - Sani E. (eds.), Le maioliche rinascimentali nelle collezioni della Fondazione Cassa di Risparmio di Perugia, vol. 2 (Città di Castello: 2007) 54-65.

Middione R., "La Sezione presepiale", in Spinosa N. - Muzii R. - Pezzullo A. (eds.), La Certosa e il museo di San Martino: Museo nazionale di San Martino (Naples: 2002).

Paolinelli C., Lacrime di smalto. Plastiche maiolicate tra Marche e Romagna nall'età del Rinascimento (Ancona: 2014).

Poole J.E., Italian Maiolica and Incised Slipware in the Fitzwilliam Museum Cambridge (Cambridge: 1995).

Previtali G., "Il Bambin Gesù come immagine devozionale nella scultura italiana del Trecento", Paragone 21 (1970) 31-40.

54 Thornton D., The Scholar in his Study: Ownership and Experience in Renaissance Italy (New Haven-London: 1997) 142-167, for a discussion of maiolica inkstands see 165-167. 
Rublack U., "Female Spirituality and the Infant Jesus in Late Medieval Dominican Convents", in Scribner B. - Johnson T. (eds.), Popular Religion in Germany and Central Europe, 1400-180o (Houndsmills-Basingstoke-London: 1996) 16-37.

Sani E., Italian Renaissance Maiolica (London: 2012).

Sarnecka Z., in Corry M. - Howard D. - Laven M. (eds.), Madonnas and Miracles: The Holy Home in Renaissance Italy, (London: 2016) 22-23, 80-81, 92-93.

Schlegel U., "The Christ Child as Devotional Image in Medieval Italian Sculpture", The Art Bulletin $5^{2}$ (1970) 1-10.

Spallanzani M., Ceramiche alla Corte dei Medici nel Cinquecento (Modena: 1994). 